\title{
Teacher's Strategy for Implementing Multiculturalism Education Based on Local Cultural Values and Character Building for Early Childhood Education
}

\author{
Dharlinda Suri ${ }^{1}$ \\ ${ }^{1}$ STKIP PGRI Bandar Lampung, Indonesia
}

\author{
Dharnita Chandra \\ Doctoral Student at Universitas Pasundan, Bandung, Indonesia
}

\begin{abstract}
The introduction of multicultural education based on local cultural values and school-level character building in early childhood education is essential so that children can recognize the diversity around them, be it ethnic, ethnic, religious, race, or culture. This field research of early childhood education teachers in Lampung, Indonesia, sought to determine the learning strategies teachers used in implementing multicultural education based on local cultural values and characterbuilding at the level of early childhood education. The study found that teachers in early childhood education used contribution, enrichment, transformation, and problem-based learning strategies. While these four strategies can develop conducive learning conditions that consider students' uniqueness, a teacher needs a clear vision and goals to facilitate multicultural education. Early childhood education must provide knowledge and help develop attitudes and behaviors for all students and school members to foster and implement educational interactions based on multiethnic and multicultural values in the school environment.
\end{abstract}

Keywords: multicultural education, local culture, learning strategies, character building, Indonesia.

Multicultural education in Indonesia is still relatively new and has not been implemented as in the United States. Indeed, multicultural education only began to be discussed in Indonesia after President Suharto New Order regime's ended in 1998. The end of the New Order that had imposed "uniformity" led to a recognition of Indonesia's diverse, multicultural heritage. Indonesia is one of the largest multicultural countries in the world, with broad socio-cultural and geographical aspects. There are more than 17,000 large and small islands in the territory of Indonesia, and a population of approximately 270 million people, consisting of 1,300 distinct ethnic groups who use nearly 700 local languages and Indonesian. In addition, Indonesians also adhere to various religions and beliefs such as Islam, Catholicism, Protestant Christianity, Hinduism, Buddhism, and Confucianism (Hoon, 2017; Mazid et al., 2021; Susanto et al., 2020; Wardhani et al., 2018).

Multicultural education is relevant in the realm of education in Indonesia as a pluralistic nation (Egerer et al., 2019; Masuda \& Yudhistira, 2020). According to Rachmadtullah et al.. (2020), multicultural education can overcome ethnic, religious, linguistic, gender, class, social, and racial differences so that the learning process becomes more effective if effective teaching-andlearning strategies are used. A primary concept in multicultural education is that the cultures of all

${ }^{1}$ Corresponding Author E-Mail: dharlindasurii@gmail.com 
students are equally valued (Agirdag et al., 2016; Egerer et al., 2019; Mahon, 2017; Ningsih, 2007; onbuloglu et al., 2016).

One area in Indonesia that requires multicultural education is Lampung Province. Located on the southern tip of Sumatra Island, Lampung became the destination of immigrants from Sumatra Island itself and Java Island. Lampung has a heterogeneous population from various ethnic groups, including Semendo (South Sumatra), Bali, Lombok, Java, Minang or Padang, Batak, Sundanese, Madurese, Bugis, Banten, Palembang, Acehnese, Makassarese, descendants, and foreigners (Chinese, Arab). In this context, multicultural education offers an alternative approach through applying learning strategies based on utilizing the diversity that exists, including ethnicity, culture, language, religion, social status, and gender (Cherng \& Davis, 2019; Gutentag et al., 2018; Paul-Binyamin \& Haj-Yehia, 2019; Spijkerboer, 2017). The most important thing in multicultural education is that an educator must master and teach subjects and instill core values like democracy, humanism, and pluralism and an appreciation of inclusive diversity in students (Foner et al., 2019; Gezer, 2018; Parkhouse et al., 2019).

Currently, some children in Lampung mock each other about social status, cultural differences, religious differences, and skin color differences. Behaviors like this cannot be left alone because they will become engrained as the children grow up, leading to schisms in society. One potential solution is to teach respect for diversity using teaching strategies to improve behavior and respect for diverse values, norms, and morals. This means implementing multicultural education based on local cultural values and character building in early childhood education.

Multicultural education must be applied in early childhood. If children are not equipped with the values of tolerance, what will the future of the Indonesian nation be like? The cultivation of values of tolerance, morals, and character is the responsibility of the government and schools and parents (Abdullah \& Abdullah, 2018; Pacini-Ketchabaw \& Bernhard, 2012). Thus, teachers and parents must work together to instill tolerance in children. In addition, early childhood is an age where children experience considerable psychological and social development, so multicultural education at an early age offers great potential to build a harmonious atmosphere in the nation (Aslan \& Aybek, 2020; Rusli, 2020; Wardle, 2018). The first six years of a person's life is a "golden age" for learning and development, so educational actors must make substantial efforts to instill basic values in children early on (Nganga, 2020; Sumadi et al., 2019).

This study addresses the urgency of multicultural education for early childhood in a situation in which differences in culture, religion, race, ethnicity and others might negatively impact the interactions of the Indonesian people. In the face of ethnic diversity and the absence of tolerance, even slight differences lead to a loss of brotherhood, unity, and life, so destructive conflicts can occur. In a study of diverse areas of East Java, Budirahayu and Saud (2021) noted that multicultural discourse is necessary to promote harmony, social justice and create an integrated environment in society. Thus, this study seeks to provide solutions in the form of teacher learning strategies to implement multicultural education based on local cultural values and school-level character building in early childhood education.

\section{Multicultural Education based on Local Cultural Values}

Paolo Freire was an advocate of dialogic pedagogy, which stressed a learning dialogue between teachers and students, nurturing students' critical thinking. One important point of this method is that the relationship between students and contact with the surrounding environment makes students understand and understand the reality in which they live, which is essentially their culture (Myers et al., 2019; Veugelers, 2017; Wilder et al., 2017). Multicultural education should 
be viewed as a process to strengthen recognizing the cultural diversity that each community and culture possesses in the context of dialogic pedagogy. This recognition is critical because the reality of existence contains an essential existential need, namely the recognition that every individual or a community has a presence (culture), the recognition of which by others is imperative (Ahamer, 2012; Bozkus, 2019; Nakaya, 2018; Neto, 2021).

A new, more tolerant paradigm is needed in dealing with cultural pluralism, namely the Multicultural Education paradigm. The Multicultural Education paradigm is important because it can help students to behave and have a tolerant and inclusive view of the reality of a diverse society in terms of culture, ethnicity, race, ethnicity, and religion (Arsal, 2019; Latypova et al., 2021; Torres \& Tarozzi, 2020). Multicultural education as an alternative education should be developed and used as a model of education in Indonesia for the following reasons, First, the reality is that Indonesia is a country inhabited by various tribes, nations, ethnic religions, with diverse languages and heterogeneous cultures as well as diverse traditions and civilizations. Second, these divisions have existed since the beginning of the Indonesian nation. Third, society opposes businessoriented, commercialization, and capitalist education, which prioritizes certain groups or people. Fourth, society does not want violence and arbitrariness in the implementation of everyone's rights. Fifth, multicultural education provides resistance to the fanaticism that leads to violence and arbitrariness. Sixth, multicultural education provides hope in overcoming various societal turmoil that has occurred recently. Seventh, multicultural education has human, social, and spiritual values (Ardhian et al., 2020; Rachmadtullah et al., 2020; Syahputra, 2020).

The diversity of race, ethnicity, ethnicity or religion reflects the unique and complicated nature of the country, and the existence of a multicultural society provides added value (Rachmadtullah et al., 2020; Satianingsih et al., 2020). Indonesia's multicultural society is based on the ideology of multiculturalism that is expressed in the nation's official motto, Bhinneka Tunggal Ika, translated as Unity in Diversity, which underlies the structural features of Indonesian society at the national and local levels. The factors causing the emergence of a multicultural society are geographical conditions and a polyglot of cultures, religions, and customs. Thousands of islands stretch from the West to the East, from Sumatra to Papua. Each island has its distinct mixture of ethnicity, religion and race (Fatonah, 2019).

The concept of multiculturalism emphasizes the importance of seeing the world from different cultural reference frames and recognizing and appreciating the richness of cultural diversity within the country and in the global community. Multiculturalism emphasizes the need to create schools where differences related to race, ethnicity, gender, sexual orientation, limitations, and social class are recognized, and all students are seen as valuable for enriching the teaching and learning process (Banks \& Banks, 2019).

Banks (2015) argues that multicultural education comprises a set of beliefs and explanations that recognize and assess the importance of cultural and ethnic diversity in shaping lifestyles, social experiences, personal identities, educational opportunities from individuals, groups and countries. He defines multicultural education as an idea, movement, educational reform and educational process whose main goal is to change the structure of educational institutions so that students with various backgrounds will have equal opportunities to achieve academic achievement in schools (Banks, 2009). Dulay (2017) argues a reciprocal relationship exists among self-concept, academic achievement, individual identity, ethnicity and culture.

Multicultural education looks at society more broadly. Based on the basic view that the attitude of "indifference" and "non-recognition" is rooted in the inequality of racial structures, the multicultural education paradigm includes subjects regarding injustice, poverty, oppression and 
underdevelopment of minority groups in various fields: social, cultural, economy, education and so on. Paradigms like this will encourage the growth of "ethnic studies" to find their place in the education curriculum from elementary to tertiary levels. The core objective of the discussion on this subject is to achieve empowerment for minority and disadvantaged groups (Banks, 2009).

The term "multicultural education" can be used at a descriptive and normative level, describing educational issues and problems related to multicultural societies. Furthermore, it also includes an understanding of the consideration of educational policies and strategies in a multicultural society must include subjects such as tolerance, themes of ethnocultural and religious differences, the dangers of discrimination, conflict resolution and mediation, human rights, democracy and plurality, multiculturalism, universal humanity and other relevant subjects

\section{Character Building}

Character building in early childhood is an effort to inculcate commendable behavior in children, behavior in worship, behavior as a good citizen, behavior in interacting with other people and the environment, and commendable behavior that is beneficial for a successful life (Burroughs, 2018). Character building is carried out in every environment where children are located. The family environment is the first environment that children encounter. Parents have a responsibility to instill good attitudes in children. Parents should not hand over the character building of their children to a teacher. Parents and teachers are models that children will imitate, both in words and actions. Children's character can be instilled through advice, habituation, example, and reinforcement (Kress \& Elias, 2019; Lottman et al., 2017).

Character education is education with a direct approach to students to instill moral values to prevent prohibited behavior. Character education is closely related to individual psychology. With character education, views can be taught about the values of life, for example, honesty, caring, responsibility, to faith (Santrock, 2011). The application of character building in early childhood can occur in daily activities by teaching independence, discipline, and responsibility to prepare children to follow the next level of education and adulthood. Kindergarten starts children on a formal path, a goal of which is to prepare students with character. Education is essentially an effort to build cognitive, affective and psychomotor intelligence. Therefore, education is continuously built and developed to produce a superior generation, excellent in knowledge, faith and practice. One effort to improve the quality of human resources is the emergence of the idea of character building in the world of education (Mei-Ju et al., 2014).

The term character building has been around since the 1900s. According to Lickona (2009), character-building contains three main elements, namely knowing the good, loving the good (desiring the good), and doing the good (doing the good). Character building does not just teach children what is right and wrong; more than that, character-building instills good habits (habituations) so that students understand, can feel, and want to do good. So, this character-building carries the same mission as moral education or moral education. According to Lickona (2009), character is related to moral concepts (moral knowing), moral attitudes (moral feeling), and moral behavior (moral behavior). Based on these three components, good character is supported by knowledge of goodness and the desire to do good deeds. In this regard, he stated, "character education is the deliberate effort to help people understand, care about, and act upon core ethical values".

Character education is education that prioritizes the essence and meaning of morals and morals so that it will be able to form good student personalities. In general, the function of this education is to shape a student's character so that he becomes a moral person, has a noble character, 
is tolerant, tough, and behaves well. The function of character education is to develop the basic potential in humans so that they become individuals who think well, have a good heart and behave well, to build and strengthen the behavior of a multicultural society, and to build and improve the nation's civilization that is competitive in international relations. Character education should be done from an early age, namely from childhood. This education can be carried out in the family, school, and neighborhood environment or various learning media (Berkowitz, 2021).

\section{Method}

\section{Research Design}

This research was qualitative encompassing field research, using descriptive data in the form of written or spoken words from people and observable behavior (Bryman, 2017). The research report provides data excerpts from interview scripts and field notes on teacher learning strategies in implementing multicultural education based on local cultural values and school-level character building in early childhood education.

\section{Participants}

The forty participants were childhood education teachers who applied teacher learning strategies in implementing multicultural education based on local cultural values and school-level character building in early childhood education. The choice of the place for this research was the Early Childhood Education school in Lampung Province; Lampung Province is a forum for ethnic, cultural and linguistic diversity. Lampung Province is the southernmost province on the island of Sumatra and bordered on the north by South Sumatra Province, on the south by the Sunda Strait, on the west by Bengkulu Province, on the east by the Java Sea. Lampung Province covers 35,587 $\mathrm{km} 2$ and once was the territory of the Tarumanagara Kingdom and the Sunda Kingdom. The province houses various ethnic groups, ranging from Javanese (60.10\%), Lampung ethnicity (21.9\%), Sundanese (10.50\%), Minangkabau (3.57\%), Balinese (1.73\%), Chinese, Malay and others $(2.15 \%)$. With the diversity of ethnic and cultural groups in Lampung, a model of multicultural education for early childhood must be presented to provide alternative schemes to build student character and character of the nation with efforts to form, familiarize, instill values of tolerance, democracy, equality and justice, thus giving birth to an attitude of mutual respect and respect since.

\section{Table 1}

Profile of participants

\begin{tabular}{llcl}
\hline & & Frequency & Percent \\
\hline Gender & Male & 11 & $27,5 \%$ \\
& Female & 29 & $72.5 \%$ \\
\hline Age & $<35$ years & 28 & $70 \%$ \\
& 35 years $>$ & 12 & $30 \%$ \\
\hline Education & Bachelor & 39 & $95.5 \%$ \\
& Master & 1 & $2.5 \%$ \\
\hline Period of employment & < year & 32 & $80 \%$ \\
& 5 year $>$ & 8 & $8 \%$ \\
\hline
\end{tabular}




\section{Data Collection}

Based on the objectives of this research, the following methods were used for data collection: 1) interviews, 2) observation, and 3) documentation (Miles \& Huberman, 2002). The authors conducted interviews about the focus of this research, namely the teacher's learning strategy in implementing multicultural education based on local cultural values and school-level character building in early childhood education, regarding planning multicultural education strategies based on local cultural values and school-level character building in early childhood education and what learning strategies that teachers used. These interviews were semi-structured, lasting between sixty and one hundred twenty minutes each and recorded for later review. They were conducted from date to date (when were they conducted). Participants were assigned pseudonyms. Field observations were made by collecting data about multicultural and learning strategies in early childhood education. The documents collected to support the data in this study were the learning implementation plan documents, student profile documents and student report cards.

\section{Data Analysis}

The stages carried out in the qualitative data analysis of this study were as follows:

1. Reading and studying the data obtained from the interview process, observation, documentation, and field notes, marking keywords and important ideas in the data;

2. Studying the keywords, coding the title of a particular conversation, then finding the themes that emerged from the data.

3. After being coded, the data were studied and reviewed again, then sorted and tested to be included in certain themes; collecting, sorting, and classifying data into each theme; looking for and finding patterns and relationships, making general findings, drawing conclusions, and providing an overview.

\section{Results}

This study examined how teacher's strategies for implementing multicultural education based on local cultural values on character building for early childhood in Lampung Province, Indonesia. The research findings are important because the main purpose of multicultural education is to instill sympathy, respect, appreciation, and empathy for adherents of different religions and cultures. Furthermore, adherents of different religions and cultures can learn to fight against intolerance, prevent religious wars, and decrease discrimination and cultural hegemony. Four themes emerged from these findings that describe how teachers develop and prepare strategies in the application of multiculturalism education based on local cultural values on character building for early childhood. The four themes were contribution strategy, enrichment strategy, transformation strategy, and problem-based learning strategy.

\section{Contribution Strategy}

Students were asked to participate in understanding and appreciating cultures different from theirs. In its practical implementation, students were invited to choose and read books together and doing joint activities. In addition, students were also encouraged to appreciate religious and cultural events found in people's lives. Educational supervisors (principals, teachers) can involve students 
in lessons or experiences related to these events. In certain cases, students can also explore a small part of the diversity of each cultural and religious tradition.

Contribution learning strategies allow students to learn by selectively observing, remembering and imitating what a teacher modeled. In addition, the contribution learning method prioritizes a declarative approach emphasizing the process of learning concepts and motor skills, thus creating a more structured learning atmosphere. One important consideration in applying the contribution learning method is to avoid conveying knowledge that is too complex.

A teacher who uses the contribution learning strategy is responsible for identifying the learning objectives, material structure, and basic skills to be taught. A teacher must convey knowledge to students, provide modeling or demonstrations, and provide opportunities for students to practice applying the concepts/skills learned to become a permanent part of a student's character. Several teacher informants said that they often used this strategy because it was sufficient to help students understand social realities in society, tolerance, culture, religious differences, race, ethnicity, and language differences. Teacher TC 10 and Teacher TC 13 said:

In using this strategy, the clarity of the teacher's instructions to students about the importance of multiculturalism education will determine the success of [its] implementation ... Likewise, the seriousness of students about Multiculturalism Education contributes to the influence. (TC 10)

With this strategy of contributing to learning activities about multiculturalism education based on local cultural values, students learn by selectively observing, remembering and imitating some examples and are practiced by playing roles about mutual respect, respect, tolerance regarding differences in religion, culture, ethnicity and race. (TC 13)

In implementing the contribution learning strategy, teachers must express information using various interesting learning media, for example, by playing folk songs, films about local wisdom in regions in Indonesia, interactive multimedia and other teaching aids related to tolerance between religions, ethnicities, races, cultures and natural resources in areas in Indonesia.

The use of contributing learning strategies in applying local cultural value-based multiculturalism education creates creative and meaningful learning, closely related to Vygotsky's theory of constructivism and zone of proximal development. Also, Piaget (1981) explained that every student brings the understanding and prior knowledge he already has into every learning process that must be added, modified, updated, revised and changed by the information encountered in the learning process. Using learning strategies that contribute to implementing multiculturalism education based on local cultural values and character building for early childhood cannot be separated from activities and interactions because opinions and activities are carried out through dialogues.

Meaningful learning with a contribution learning strategy in implementing multiculturalism education is characterized by the relationship between aspects, concepts of information, or new situations with relevant components in students' cognitive structure. In learning strategies, the contribution to implementing multiculturalism education is not merely memorization but the development of a meaningful learning process to connect concepts to produce a complete understanding so that concepts are learned and understood holistically. 


\section{Enrichment Strategy}

This strategy enriches the curriculum with information from or about people of different cultures or religions. For example, one application of this strategy is to invite students to assess or examine and then appreciate a community's perspective. This strategy faces the same problem as the contributive strategy, namely, the material studied is usually always based on the perspective of events, concepts, ideas and issues presented from the dominant perspective. Enrichment learning is additional learning to provide new learning opportunities for students so that they can optimize their understanding. TC 12 said:

This learning ... is based on a theory that holds that learning depends on the experience of students. Teaching in this model prioritizes a declarative approach with an emphasis on the process of learning concepts and skills of students so that it can create a more structured learning atmosphere in accordance with the nature of multiculturalism education based on local cultural values on character building. (TC 12)

The implementation of enrichment learning can be carried out through activities like group learning, independent learning, and theme-based learning, providing enrichment learning only for competencies/materials that are unknown to students. Thus, students gain new competencies/materials about multiculturalism. As TC 15 noted:

Enrichment can be done through individual or group learning assignments, adjusted to the type of task and the abilities of each student. Usually, the teacher gives assignments such as showing videos on religious diversity and respecting the culture of friends who have different religions, ethnicities, and races. After showing the video, I often give an understanding of the importance of applying multiculturalism education. (TC 15)

This strategy allows learners to see concepts from several cultural, ethnic and religious perspectives critically. This method requires including perspectives, frames of reference and ideas that will broaden the learner's understanding of an idea. In general, enrichment learning strategies can be interpreted as experiences or activities of students that exceed the minimum requirements that the multiculturalism education curriculum has determined, and not all students can do it. As Walter (2018) noted, enrichment activities are activities provided to students so that they become richer in knowledge and skills or so that their mastery is deeper on the subject matter and competencies. Enrichment activities are a form of service provided to one or several students who are very fast in learning and need additional tasks to increase the knowledge and skills they already have gained in learning activities about multiculturalism.

\section{Transformative Learning Strategy}

Transformative learning is learning that requires a change in the way of thinking or mindset of students. This mindset change often occurs through a social process where students understand that social and cultural relationships affect their beliefs and feelings about multiculturalism. TC 17 said, 
We apply a strategy of transformative learning methods in applying the values of multiculturalism education. Students cannot be separated from cultural values, and this method can change children's mindsets about that differences are very beautiful and in maintaining the unity of a country must understand each other the importance of differences. (TC17)

\section{Problem-Based Learning Strategy}

The problem-based learning approach in early childhood learning is quite common because it helps students understand a problem in more depth and find a solution to a problem. In this problem-based learning strategy, the teacher's role is to present various problems, ask questions, and facilitate investigation and dialogue. The teacher provides the opportunity for students to determine the topic of the problem to be discussed, even though the teacher has already determined what problem topic should be discussed. The most important thing is that the teacher provides a scaffold or a supporting framework to improve students' investigative abilities and intelligence in thinking. The learning process is directed so that students are able to solve problems systematically and logically. This learning model can occur if the teacher can create an open and honest classroom environment because the classroom itself is a place to exchange students' ideas in responding to various problems.

If viewed from the point of view of learning psychology, this learning model is based on cognitive psychology, which is rooted in the assumption that learning is a process of changing behavior due to experience. Through this learning model, students can develop as a whole, meaning not only cognitive development but also automatically develop in the affective and psychomotor fields through the problems they face. Problem-based learning strategies take cognitive psychology as their theoretical support. The focus of learning in this model emphasizes what students think while involved in the learning process, not on what they do in the learning process.

A problem-based learning strategy is a learning concept that helps teachers create a learning environment that starts with important and relevant problems and allows students to have a more realistic learning experience. Problem-based learning engages students in an active, collaborative, learner-centered learning process, which develops the problem-solving and independent learning skills needed to face challenges in life and careers in today's increasingly complex environment. Problem-based learning can also be started by doing group work between students. Students investigate themselves, find problems, then solve the problem under the guidance of the facilitator (teacher). Two teachers expressed their views about problem-based learning strategies in applying multiculturalism education based on local cultural values. TC 21 and TC 24 said,

This problem-based learning strategy is very often used by teachers because it is considered sufficient to help students understand social realities in society, but also because it is very effective in teaching values and norms that exist in society, such as the value of courtesy in expressing opinions, tolerance and the value of respecting the opinions of others. (TC 21) 


\begin{abstract}
This strategy is a very good learning strategy in implementing multiculturalism education. Problem-based learning strategies must start with the awareness of problems that must be solved. At this stage, the teacher guides students to the awareness of gaps or gaps felt by humans or the social environment. The ability that must be achieved by students, at this stage, is that students can determine or capture gaps that occur from various existing phenomena. (TC 24)
\end{abstract}

In determining the problem to be discussed, TC 24 said that he only gave the students an idea of how to determine a problem to be discussed, then the students themselves in the group decided what problems they would take to be dissected together. Problem-Based Learning (PBL) strategy is a learning model with a student learning approach to authentic problems to construct their own knowledge, develop higher skills and inquiry, become independent students and increase self-confidence (Phungsuk et al., 2017). The use of real-life problems characterizes this model as something that students must learn to practice and improve critical thinking and problem-solving skills and gain knowledge of important concepts, where the teacher's task must focus on helping students achieve self-direction skills.

\title{
Discussion
}

In addition to building students' skills, a teacher is also expected to be a transformer of multicultural education capable of instilling the values of democracy, pluralism, and humanism in their students directly at school. The most important thing in multicultural education is that a teacher is required to master and be able to teach the subjects he teaches professionally and must also be able to instill the core values of multicultural education such as democracy, pluralism, and humanism. Multicultural education views that education is no longer a place for discrimination based on race, ethnicity, gender, or family background.

Multicultural education involves a teacher's role in creating justice in the learning process. Teachers are expected to be able to manage learning situations and provide learning activities that are full of mutual respect and tolerance. Multicultural education is a process of applying a way of life that respects, appreciates, and is sincere and is tolerant of the diversity that lives in the midst of a pluralistic society (Dameron et al., 2020; Gonzalez-Voller et al., 2020).

The strategies that early childhood education teachers used in implementing multicultural education based on local cultural values used four learning strategies: 1) contribution, 2) enrichment, 3) transformation, and 4) problem-based learning. These learning strategies include specific approaches, models, methods and learning techniques. Learning strategies have several uses and benefits, one of which is that the needs of students are served regarding learning how to think better. In addition, the existence of learning strategies also helps teachers to have an idea of how to engage in multicultural education. This is because students have differences in terms of ability, motivation to learn, and socio-cultural backgrounds. Indeed, Ansori et al. (2020) suggested that selecting strategies for implementing multicultural education must be adjusted to the conditions and adapted to the learning environment.

Multicultural education is essential for laying the foundation for developing a more open, tolerant, and democratic Indonesian society. This education should focus on cognitive or knowledge dimensions as well as affective and psychomotor dimensions. Implementing multicultural approaches to education is critical because every child comes to school with an ethnic identity, whether consciously or not (Khalfaoui et al., 2021). Teachers must recognize and 
understand these identifications. This should be the basis for learning activities in the classroom. The point is to acknowledge the differences, not ignore them. It is equally important when students recognize and value their ethnic identities and learn to respect those of others in the classroom. The introduction of each ethnic identity is the starting point; this is a liaison between teachers and students and students with other students (Bennett et al., 2018). Ethnic identification as a followup point that focuses on the entire educational process is the basis for developing the next level of identification, namely national identification. Identifying each individual requires understanding and commitment to democratic ideals such as human dignity, justice and equal rights. Here the focus is on being an effective member of a democratic society. Strong national identification of each individual is central to developing a global identity (Rowan et al., 2021).

Schools at the early childhood education level are the right institutions in which to ground multicultural education amidst concerns about the dangers of national disintegration. In multicultural education held in schools, all elements of the school have a fairly central role. Teachers and school leaders also have a vital role in multicultural education, where the policies they produce can lead to a condition that demands an understanding of the differences and diversity that exists (Dameron et al., 2020).

\section{Conclusion}

This study found that teachers engaged in four learning strategies: contribution learning strategies, enrichment learning strategies, transformation learning strategies, and problem-based learning. These strategies provide a touchstone upon which to formulate teaching and learning activities to create innovative learning experiences regarding knowledge and analytical thinking skills in preparing students to enter life in adulthood towards multicultural education based on local cultural values and character building.

This study shows that multicultural education is based on local cultural values and character building. It is important to teach education at an early age because it introduces inter-ethnic cultural values, harmony in religion and promotes tolerance to students. The study also shows that introducing pluralism and multiculturalism to students is an excellent strategy for promoting respect and appreciation for differences among students in schools and Indonesia's diverse society.

\section{Acknowledgment}

The authors would like to thank all those who contributed to this project and are particularly grateful to STKIP-PGRI Bandar Lampung that donated funds to help complete this research.

\section{References}

Abdullah, M. N. L. Y., \& Abdullah, A. C. (2018). Preschool teachers' training and attitudes towards multicultural education in Malaysia. Southeast Asia Early Childhood Journal, 7, 1-13. https://doi.org/10.37134/saecj.vol7.1.2018

Agirdag, O., Merry, M. S., \& Van Houtte, M. (2016). Teachers' Understanding of Multicultural Education and the Correlates of Multicultural Content Integration in Flanders. Education and Urban Society, 48(6), 556-582. https://doi.org/10.1177/0013124514536610

Ahamer, G. (2012). The jet principle: technologies provide border conditions for global learning. Multicultural Education \& Technology Journal, 6(3), 177-210. 
https://doi.org/10.1108/17504971211254010

Ansori, Y. Z., Budiman, I. A., \& Nahdi, D. S. (2020). Fostering Diversity Attitudes Through the Internalization of Multicultural Values. Proceedings of the 3rd International Conference on Learning Innovation and Quality Education (ICLIQE 2019). https://doi.org/10.2991/assehr.k.200129.164

Ardhian, T., Ummah, I., Anafiah, S., \& Rachmadtullah, R. (2020). Reading and critical thinking techniques on understanding reading skills for early grade students in elementary school. International Journal of Instruction, 13(2). https://doi.org/10.29333/iji.2020.1328a

Arsal, Z. (2019). Critical multicultural education and preservice teachers' multicultural attitudes. Journal for Multicultural Education, 13(1), 106-118. https://doi.org/10.1108/JME-102017-0059

Aslan, S., \& Aybek, B. (2020). Testing the Effectiveness of Interdisciplinary Curriculum-Based Multicultural Education on Tolerance and Critical Thinking Skill. International Journal of Educational Methodology, 6(1). https://doi.org/10.12973/ijem.6.1.43

Banks, J. A. (2009). The Routledge International Companion to Multicultural Education. Routledge.

Banks, J. A. (2015). Multicultural Education. Wiley.

Banks, J. A. B., \& Banks, C. A. M. (2019). Multicultural Education: Issues and Perspectives, 10th Edition. John Wiley \& Sons.

Bennett, S. V., Gunn, A. A., Gayle-Evans, G., Barrera, E. S., \& Leung, C. B. (2018). Culturally Responsive Literacy Practices in an Early Childhood Community. Early Childhood Education Journal, 46(2), 241-248. https://doi.org/10.1007/s10643-017-0839-9

Berkowitz, M. W. (2021). Implementing and Assessing Evidence-Based Character Education. Journal of Education, 002205742110269. https://doi.org/10.1177/00220574211026908

Bozkus, K. (2019). The Attitudes of Teachers towards Multicultural Education. European Journal of Educational Research, 8(1). https://doi.org/10.12973/eu-jer.8.1.383

Bryman, A. (2017). Quantitative and qualitative research: further reflections on their integration. In Mixing Methods: qualitative and quantitative research (pp. 57-78). Routledge. https://doi.org/10.4324/9781315248813-3

Budirahayu, T., \& Saud, M. (2021). Proposing an Integrated Multiculturalism Learning System: A Study from Indonesian Schools. The Asia-Pacific Education Researcher, 30(2), 141-152. https://doi.org/10.1007/s40299-020-00521-1

Burroughs, M. D. (2018). Ethics Across Early Childhood Education. In Ethics Across the Curriculum-Pedagogical Perspectives (pp. 245-260). Springer International Publishing. https://doi.org/10.1007/978-3-319-78939-2_15

Cherng, H.-Y. S., \& Davis, L. A. (2019). Multicultural Matters: An Investigation of Key Assumptions of Multicultural Education Reform in Teacher Education. Journal of Teacher Education, 70(3), 219-236. https://doi.org/10.1177/0022487117742884

Dameron, M. L., Camp, A., Friedmann, B., \& Parikh-Foxx, S. (2020). Multicultural Education and Perceived Multicultural Competency of School Counselors. Journal of Multicultural Counseling and Development, 48(3), 176-190. https://doi.org/10.1002/jmcd.12176

Dulay, S. (2017). The Effect of Self-concept on Student Achievement. In The Factors Effecting Student Achievement (pp. 117-132). Springer International Publishing. https://doi.org/10.1007/978-3-319-56083-0_7

Egerer, M., Ordóñez, C., Lin, B. B., \& Kendal, D. (2019). Multicultural gardeners and park users benefit from and attach diverse values to urban nature spaces. Urban Forestry \& Urban Greening, 46, 126445. https://doi.org/10.1016/j.ufug.2019.126445 
Fatonah, I. (2019). The Role of Multicultural Education towards the Strengthening of Bhinneka Tunggal Ika (Case Study University of Muhammadiyah Metro). ADDIN, 13(1), 149. https://doi.org/10.21043/addin.v13i1.2871

Foner, N., Duyvendak, J. W., \& Kasinitz, P. (2019). Introduction: super-diversity in everyday life. Ethnic and Racial Studies, 42(1), 1-16. https://doi.org/10.1080/01419870.2017.1406969

Gezer, M. (2018). An analysis of correlations between prospective teachers' philosophy of education and their attitudes towards multicultural education. Cogent Education, 5(1), 1475094. https://doi.org/10.1080/2331186X.2018.1475094

Gonzalez-Voller, J., Crunk, A. E., Barden, S. M., Harris, S., \& Belser, C. T. (2020). A Preliminary Longitudinal Study of Multicultural Competence in Counselor Education. Journal of Counseling \& Development, 98(3), 308-318. https://doi.org/10.1002/jcad.12325

Gutentag, T., Horenczyk, G., \& Tatar, M. (2018). Teachers' Approaches Toward Cultural Diversity Predict Diversity-Related Burnout and Self-Efficacy. Journal of Teacher Education, 69(4), 408-419. https://doi.org/10.1177/0022487117714244

Hoon, C.-Y. (2017). Putting Religion into Multiculturalism: Conceptualising Religious Multiculturalism in Indonesia. Asian Studies Review, 41(3), 476-493. https://doi.org/10.1080/10357823.2017.1334761

Khalfaoui, A., García-Carrión, R., \& Villardón-Gallego, L. (2021). A Systematic Review of the Literature on Aspects Affecting Positive Classroom Climate in Multicultural Early Childhood Education. Early Childhood Education Journal, 49(1), 71-81. https://doi.org/10.1007/s10643-020-01054-4

Kress, J. S., \& Elias, M. J. (2019). Nurturing Students' Character. Routledge. https://doi.org/10.4324/9780429199875

Latypova, E., Kozmenko, V., \& Toktamysov, S. (2021). Multicultural Education of Autochthons and Migrants in Russia. Journal of Ethnic and Cultural Studies, 8(3), 203. https://doi.org/10.29333/ejecs/751

Lickona, T. (2009). Educating for Character: How Our Schools Can Teach Respect and Responsibility Bantam Trade Paperback Ed Edition. Bantam.

Lottman, T. J., Zawaly, S., \& Niemiec, R. (2017). Well-Being and Well-Doing: Bringing Mindfulness and Character Strengths to the Early Childhood Classroom and Home. In Positive Psychology Interventions in Practice (pp. 83-105). Springer International Publishing. https://doi.org/10.1007/978-3-319-51787-2_6

Mahon, J. A. (2017). Intercultural and Multicultural Education. In The International Encyclopedia of Intercultural Communication (pp. 1-9). Wiley. https://doi.org/10.1002/9781118783665.ieicc0183

Masuda, K., \& Yudhistira, M. H. (2020). Does education secularize the Islamic population? The effect of years of schooling on religiosity, voting, and pluralism in Indonesia. World Development, 130, 104915. https://doi.org/10.1016/j.worlddev.2020.104915

Mazid, S., Futaqi, S., \& Farikah, F. (2021). The Concept of "Freedom of Learning" In A $\begin{array}{llll}\text { Multicultural } \quad \text { Education } \quad \text { Perspective. } & T a a^{\prime} d i b, & 24(1), & 70 .\end{array}$ https://doi.org/10.31958/jt.v24i1.2759

Mei-Ju, C., Chen-Hsin, Y., \& Pin-Chen, H. (2014). The Beauty of Character Education on Preschool Children's Parent-child Relationship. Procedia - Social and Behavioral Sciences, 143, 527-533. https://doi.org/10.1016/j.sbspro.2014.07.431

Miles, M. B., \& Huberman, M. (2002). The qualitative researcher's companion. Sage Publication. Myers, W. R., Pippin, T., Carvalhaes, C., \& De Anda, N. (2019). Forum on Paulo Freire's 
pedagogy: Leaning educationally into our future. Teaching Theology \& Religion, 22(1), 56-72. https://doi.org/10.1111/teth.12472

Nakaya, A. (2018). Overcoming Ethnic Conflict through Multicultural Education: The Case of West Kalimantan, Indonesia. International Journal of Multicultural Education, 20(1), 118. https://doi.org/10.18251/ijme.v20i1.1549

Neto, F. (2021). Intercultural Relations Among Guinean Immigrants Living in Portugal: Testing Multiculturalism, Contact, and Integration Hypotheses. Journal of Ethnic and Cultural Studies, 8(2), 225. https://doi.org/10.29333/ejecs/641

Nganga, L. (2020). Analyzing Children's Literature for Hidden Bias Helps Preservice Teachers Gain Pedagogical Practices in Critical Multicultural Education. Journal of Research in Childhood Education, 34(1), 93-107. https://doi.org/10.1080/02568543.2019.1692109

Ningsih, S. (2007). The Role of Teachers in Embedding Multicultural Values of State High School 1 Sidomulyo Students [Peran Guru Dalam Menanamkan Nilai nilai multikultural Peserta Didik Sekolah Menengah Atas Negeri 1 Sidomulyo]. Universitas Lampung.

Pacini-Ketchabaw, V., \& Bernhard, J. K. (2012). 5. Revisioning Multiculturalism in Early Childhood Education. In Recent Perspectives on Early Childhood Education in Canada (pp. 159-181). University of Toronto Press. https://doi.org/10.3138/9781442662032-008

Parkhouse, H., Lu, C. Y., \& Massaro, V. R. (2019). Multicultural Education Professional Development: A Review of the Literature. Review of Educational Research, 89(3), 416458. https://doi.org/10.3102/0034654319840359

Paul-Binyamin, I., \& Haj-Yehia, K. (2019). Multicultural education in teacher education: Shared experience and awareness of power relations as a prerequisite for conflictual identities dialogue in Israel. Teaching and Teacher Education, 85, 249-259. https://doi.org/10.1016/j.tate.2019.06.021

Phungsuk, R., Viriyavejakul, C., \& Ratanaolarn, T. (2017). Development of a problem-based learning model via a virtual learning environment. Kasetsart Journal of Social Sciences, 38(3), 297-306. https://doi.org/10.1016/j.kjss.2017.01.001

Piaget, J. (1981). Comentarios sobre las observaciones críticas de Vygotsky. Infancia $y$ Aprendizaje, 4(sup1), 37-48. https://doi.org/10.1080/02103702.1981.10821887

Rachmadtullah, R., Syofyan, H., \& Rasmitadila. (2020). The role of civic education teachers in implementing multicultural education in elementary school students. Universal Journal of Educational Research, 8(2). https://doi.org/10.13189/ujer.2020.080225

Rowan, L., Bourke, T., L'Estrange, L., Lunn Brownlee, J., Ryan, M., Walker, S., \& Churchward, P. (2021). How Does Initial Teacher Education Research Frame the Challenge of Preparing Future Teachers for Student Diversity in Schools? A Systematic Review of Literature. Review of Educational Research, 91(1), 112-158. https://doi.org/10.3102/0034654320979171

Rusli, R. (2020). The Role of Family In Preventing Social Conflict In Society From Islamic Perspectives. HUNAFA: Jurnal Studia Islamika, 17(1), 108-122. https://doi.org/10.24239/jsi.v17i1.576.104-118

Santrock, J. W. (2011). Educational Psychology. Hill Medical Publishing.

Satianingsih, R., Budiyono, S. C., \& Subandowo, M. (2020). Character education in multicultural society: Case in Indonesia. International Journal of Multicultural and Multireligious Understanding, 7(4), 337-344.

Spijkerboer, T. (2017). Gender and Refugee Status. Routledge. https://doi.org/10.4324/9781315254692

Sumadi, T., Yetti, E., Yufiarti, Y., \& Wuryani, W. (2019). Transformation of Tolerance Values (in 
Religion) in Early Childhood Education. JPUD - Jurnal Pendidikan Usia Dini, 13(2), 386400. https://doi.org/10.21009/JPUD.132.13

Susanto, R., Rachmadtullah, R., \& Rachbini, W. (2020). Technological and Pedagogical Models: Analysis of Factors and Measurement of Learning Outcomes in Education. Journal of Ethnic and Cultural Studies, 7(2), 1. https://doi.org/10.29333/ejecs/311

Syahputra, M. C. (2020). Values of character education in Lampung local wisdom Islamic Education Perspective. In Universitas Islam Negeri Sunan Ampel Surabaya. http://digilib.uinsby.ac.id/42119/

Tonbuloglu, B., Aslan, D., \& Aydin, H. (2016). Teachers' Awareness of Multicultural Education and Diversity in School Settings. Eurasian Journal of Educational Research, 16(64), 1-28. https://doi.org/10.14689/ejer.2016.64.1

Torres, C. A., \& Tarozzi, M. (2020). Multiculturalism in the world system: towards a social justice model of inter/multicultural education. Globalisation, Societies and Education, 18(1), 718. https://doi.org/10.1080/14767724.2019.1690729

Veugelers, W. (2017). The moral in Paulo Freire's educational work: What moral education can learn from Paulo Freire. Journal of Moral Education, 46(4), 412-421. https://doi.org/10.1080/03057240.2017.1363599

Walter, J. S. (2018). Global Perspectives: Making the Shift from Multiculturalism to Culturally Responsive Teaching. General Music Today, 31(2), 24-28. https://doi.org/10.1177/1048371317720262

Wardhani, P. A., Zulela, M. S., Rachmadtullah, R., \& Siregar, Y. E. Y. (2018). Moral Literacy and Social Climate with Perception Teacher' s Character Education in Elementary School. Advances in Social Science, Education and Humanities Research, 251, 301-304.

Wardle, F. (2018). Adding to Our View of Early Childhood Multicultural Education. Childhood Education, 94(5), 34-40. https://doi.org/10.1080/00094056.2018.1516470

Wilder, L., Sanon, D., Carter, C., \& Lancellot, M. (2017). Narrative Ethnographies of Diverse Faculty in Higher Education: "Moral" Multiculturalism among Competing Worldviews. Journal of Ethnic and Cultural Studies, 4(2), 1. https://doi.org/10.29333/ejecs/76

\section{Notes on Contributors}

Dharlinda Suri - is a lecturer and practitioner from the Teacher Training College of Education - PGRI Bandar Lampung (STKIP-Bandar Lampung). He has worked in several research projects in the field of Character Education for Early Childhood, Cultural Education for Early Childhood.

Dharnita Chandra - is the Acting Head of the Tertiary Education Service Institution Region IV Ministry of Education, Culture, Research and Technology of the State of Indonesia. 